\title{
ERRATUM
}

\section{Bases of DNA repair and regulation}

Adam B Robertson, John Arne Dahl \& Arne Klungland

Nat. Chem. Biol. 10, 487-488 (2014); published online 17 June 2014; corrected after print 30 June 2014

In the version of this article initially published, the surname of the first author in reference 2 was misspelled as Pfaffender. The correct spelling is Pfaffeneder. The error has been corrected in the HTML and PDF versions of the article.

\section{ERRATUM}

\section{Notch inhibition allows oncogene-independent generation of iPS cells.}

Justin K Ichida, Julia T C W, Luis A Williams, Ava C Carter, Yingxiao Shi, Marcelo T Moura, Michael Ziller, Sean Singh, Giovanni Amabile, Christoph Bock, Akihiro Umezawa, Lee L Rubin, James E Bradner, Hidenori Akutsu, Alexander Meissner \& Kevin Eggan

Nat. Chem. Biol. 10, 632-639 (2014); published online 22 June 2014; corrected after print 29 July 2014

In the version of this article initially published, Julia TCW's name was misspelled as Julia T C W. In addition, her initials in the author contribution statement should have read J.T. instead of J.T.C.W. The error has been corrected in the HTML and PDF versions of the article.

\section{ERRATUM}

\section{Notch inhibition allows oncogene-independent generation of iPS cells}

Justin K Ichida, Julia T C W, Luis A Williams, Ava C Carter, Yingxiao Shi, Marcelo T Moura, Michael Ziller, Sean Singh, Giovanni Amabile, Christoph Bock, Akihiro Umezawa, Lee L Rubin, James E Bradner, Hidenori Akutsu, Alexander Meissner \& Kevin Eggan

Nat. Chem. Biol. 10, 632-639 (2014); published online 22 June 2014; corrected after print 29 July 2014 and 14 August 2014

In the version of this article initially published, a black bar was erroneously placed in the scrambled shRNA column in Figure $3 \mathrm{~g}$. The error has been corrected for the PDF and HTML versions of the article. 